\title{
Site Conditions, Maintenance Costs, and Plant Performance of 10 Extensive Green Roofs in the Research Triangle Area of Central North Carolina
}

\author{
Julieta Trevino Sherk ${ }^{1}$, Wenyan $\mathrm{Fu}^{1}$, and Joseph C. Neal ${ }^{1}$
}

\begin{abstract}
ADDITIONAL INDEX WORDs. maintenance practices, plant cover evaluation, stormwater management, weeds

Summary. Compared with traditional roofing, green roofs (GRs) have quantifiable environmental and economic benefits, yet limited research exists on GR plant survival, maintenance practices, and costs related to plant performance. The objective of this study was to assess plant cover, site conditions, and maintenance practices on 10 extensive GRs in the Research Triangle Area of North Carolina. Green roof maintenance professionals were surveyed to assess plant performance, maintenance practices, and maintenance costs. Vegetation cover on each site was characterized. Relationships among plant performance and environmental and physical site characteristics, and maintenance practices were evaluated. Survey respondents ranked weed control as the most problematic maintenance task, followed by irrigation, pruning, and debris removal. No single design or maintenance factor was highly correlated with increased plant cover. Green roof age, substrate organic matter, and modular planting methods were not correlated with greater plant cover. Results showed a trend that irrigation increased plant cover. Plants persisting on GRs included several species of stonecrop (Sedum sp.), but flame flower (Talium calycinum) and ice plant (Delosperma basuticum) were also present in high populations on at least one roof each. Green roof maintenance costs ranged from $\$ 0.13 / \mathrm{ft}^{2}$ to $\$ 3.45 / \mathrm{ft}^{2}$ per year, and were greater on sites with more weeds and frequent hand watering.
\end{abstract}

$\mathrm{G}$ reen roofs are an urban design strategy that improves living environments while supporting ecological, economic, and ornamental purposes (Oberndorfer et al., 2007). GRs fall into two broad categories: "intensive" and "extensive." Intensive GRs have more than 6 inches of planting substrate and can thus support a diversity of vegetation including small trees, shrubs, or forbs. Intensive GRs are incorporated into a building structure's design, and are generally impractical as a retrofit because of the substrate depth and weight, which demand higher structural requirements. In contrast, extensive GRs are defined by a substrate depth of less than or equal to 6 inches.

Received for publication 14 Apr. 2020. Accepted for publication 6 Aug. 2020.

Published online 25 September 2020.

${ }^{1}$ Department of Horticultural Science, North Carolina State University, 166 Kilgore Hall, Campus Box 7609, Raleigh, NC 27695-7609

J.T.S. is the corresponding author. E-mail: jtsherk@ ncsu.edu.

This is an open access article distributed under the CC BY-NC-ND license (https://creativecommons.org/ licenses/by-nc-nd/4.0/).

https://doi.org/10.21273/HORTTECH04565-20
Because of the shallower substrate depth, plant choices for extensive GRs are often limited to drought-tolerant and/or shallow-rooted species, such as herbs, grasses, mosses, and succulents such as stonecrops (Sedum sp.) (Farrell et al., 2013). Extensive GRs can be designed as part of newly constructed buildings or retrofitted into existing buildings.

Stormwater management is arguably the most significant environmental benefit of GRs, allowing for water retention, water treatment, volume reduction, and evaporation. $\mathrm{Li}$ et al. (2014) assert that GRs can reduce stormwater runoff volume by $30 \%$ to $86 \%$, reduce the peak flow rate by $22 \%$ to $93 \%$, and can delay the peak flow up to $30 \mathrm{~min}$, thereby providing valuable ecosystem services that decrease water pollution, flooding, and erosion from stormwater runoff. In addition, urban GRs have been reported to contribute to the reduction of the urban heat island effect (Santamouris, 2014), improve air quality (Rowe, 2011; Yang et al., 2008), add to carbon sequestration (Getter et al., 2009), and reduce noise (Veisten et al., 2012). Nagase and Dunnett (2012) showed that the type of vegetation may influence the amount of water runoff on extensive GRs, concluding that grasses are the most effective stormwater management species followed by forbs like stonecrop. Grasses were found to have high water demand and their taller canopies may intercept more rainfall (Dunnett et al., 2008).

Comprehensive cost-benefit analyses of GRs are lacking, particularly analyses including maintenance costs. Quantifiable cost-benefit comparisons have shown that GRs can provide cost savings, yet the amounts calculated and the methods and benefit categories used in the calculations varied among studies (Table l) (Acks, 2006; Carter and Keeler, 2008; Clark et al., 2008; Mullen et al., 2013; Niu et al., 2010; Shao, 2012; Yao et al., 2020). Among six cost-benefit analyses summarized in Table 1 , cost savings range from $\$ 0.11 / \mathrm{ft}^{2}$ to $\$ 3.32$ / $\mathrm{ft}^{2}$ per year. Yet, four of the six reports did not include maintenance costs in their analyses (Table 1). Furthermore, these studies did not describe the presence or condition of vegetation on the GR.

Proper maintenance protects GR investments and ensures the GR system achieves its original intent (Curtland, 2013). However, limited data are available on maintenance costs and practices for extensive GRs. Green roof maintenance costs have been reported to be between $\$ 0.75 / \mathrm{ft}^{2}$ to $\$ 1.50 / \mathrm{ft}^{2}$ per year (Prince George's County Department of the Environment, 2016). Similarly, Acks (2006) reported annual maintenance costs to be $\$ 0.60 / \mathrm{ft}^{2}$ for medium performance scenario GRs and $\$ 0.10 / \mathrm{ft}^{2}$ for standard roofs. As previously noted, most

\begin{tabular}{llll}
\hline $\begin{array}{l}\text { Units } \\
\text { To convert U.S. to SI, } \\
\text { multiply by }\end{array}$ & U.S. unit & SI unit & $\begin{array}{l}\text { To convert SI to U.S., } \\
\text { multiply by }\end{array}$ \\
\hline 0.3048 & $\mathrm{ft}$ & $\mathrm{m}$ & 3.2808 \\
0.0929 & $\mathrm{ft}^{2}$ & $\mathrm{~m}^{2}$ & 10.7639 \\
2.54 & inch(es) & $\mathrm{cm}$ & 0.3937 \\
1.6093 & $\mathrm{mph}$ & $\mathrm{km} \cdot \mathrm{h}^{-1}$ & 0.6214 \\
$\left({ }^{\circ} \mathrm{F}-32\right) \div 1.8$ & ${ }^{\circ} \mathrm{F}$ & ${ }^{\circ} \mathrm{C}$ & $\left({ }^{\circ} \mathrm{C} \times 1.8\right)+32$
\end{tabular}


Table 1. List of studies that evaluate cost-benefit comparisons of extensive green roof maintenance costs.

\begin{tabular}{lcc}
\hline Study & Cost savings $\left(\$ / \mathbf{f t}^{2} \text { per } \mathbf{~ y r}\right)^{\mathbf{z}}$ & Maintenance costs $^{\mathbf{y}}$ \\
\hline Carter and Keeler (2008) & $2.35-3.32$ & No \\
Mullen et al. (2013) & $1.80-2.50$ & Yes \\
Acks (2006) & $0.65-1.02$ & Yes \\
Clark et al. (2008) & $0.45-1.70$ & No \\
Yao et al. (2020) & 0.09 & Yes \\
Shao (2012) & 0.31 & No \\
Niu et al. $(2010)$ & $0.11-0.26$ & No \\
\hline
\end{tabular}

${ }^{\mathrm{z}}$ Savings realized when green roofs are used rather than traditional roofs; $\$ 1 / \mathrm{ft}^{2}=\$ 10.7639 / \mathrm{m}^{2}$.

${ }^{y} Y e s / N o$ indicate whether maintenance cost were reported in the study or not.

cost-benefit comparisons have not included the cost of maintenance, and no such data are available from environments similar to the climate of North Carolina (Beck et al., 2018). Therefore, further detailed information is needed to determine maintenance costs of site-specific locations and roof types.

To provide the wide-ranging benefits described, GRs must have high performing plant cover, as plant performance along with its associated substrate will ultimately determine the effectiveness of GRs in restorative ecological functions (Farrell et al., 2013). Choosing plants that not only survive but also thrive is important for maximizing economic and ecological benefits (Lundholm et al., 2014).

This study focuses on evaluating plant cover and maintenance strategies found on commercial/institutional GRs in the Research Triangle Area (RTA) of central North Carolina. This study's objectives were to: 1) evaluate the impact of site conditions on plant performance; 2) document maintenance practices and costs; and 3 ) investigate criteria such as planting methods, substrate composition, and maintenance practices that may improve the future GR design and performance in this region.

\section{Materials and methods}

Site selection. Ten extensive GR sites in the RTA of central North Carolina were selected for analysis. According to the North Carolina Climate Office (North Carolina State University, 2020), the RTA is located largely at longitude $78.64^{\circ} \mathrm{W}$ and latitude $35.78^{\circ} \mathrm{N}$. The area is classified by Koppen's climate classification as humid subtropical (Beck et al., 2018). The RTA has four distinct seasons with short winters with average winter snowfall of 6 inches, and with an average high temperature of $71.3^{\circ} \mathrm{F}$, average low of $50.3{ }^{\circ} \mathrm{F}$, with an average annual precipitation of 46.6 inches. The area experiences occasional droughts, hurricanes, and tropical storms, with temperatures as low as $-9^{\circ} \mathrm{F}$ and as high as $105^{\circ} \mathrm{F}$. Length of day varies between $9 \mathrm{~h}$ and $44 \mathrm{~min}$ on 21 Dec., and $14 \mathrm{~h}$ and $35 \mathrm{~min}$ on 21 June. Humidity ranges from the highest during mid-May to early October, with the highest average humidity of $86 \%$ in mid-July, and the lowest $(0 \%)$ in early February. Average wind speed is 8 to $10 \mathrm{mph}$ with the lowest monthly average of $4.7 \mathrm{mph}$ in August. Approximately once every decade higher wind speeds can occur during hurricane season (June-November) with possible sustained wind speeds of $74 \mathrm{mph}$.

With several universities as the main resources for institutional GRs and GR technology, the RTA of North Carolina provides numerous opportunities for access to extensive GRs. The study sites ranged between 1500 and $14,000 \mathrm{ft}^{2}, 2$ to 8 years in age at the time of the study, and were all on institutional buildings. The sites were selected to represent the current conditions of flat extensive GRs with 6 inches or less of growing medium at a variety of institutions in the North Carolina RTA.

SURVEY. After receiving approval from the Institutional Review Board at North Carolina State University, an online survey was conducted to assess GR maintenance staff perspectives of the quality and maintenance practices of the 10 GRs. The survey instrument questions were informed by a literature review and preliminary interviews with GR maintenance and design professionals. The survey was generated using the online survey software,
Qualtrics (Qualtrics, Provo, UT). The survey was organized into five categories: character of the GR, substrate description, plant material description, maintenance practices, and subjective open-ended questions (Table 2). The first three parts were combined into the site conditions categories, the outcomes of which are described in the results and analysis of this study. Based on the preliminary interviews with GR maintenance professionals, maintenance was divided into four parts: irrigation, weed control, growth control (pruning or mowing), and fertilizer use (Table 2). The open-ended fifth part asked participants to describe their biggest challenge; what changes they would make to the roof; and to describe which factor they thought was the most important to the success of the GR (Table 2). The survey Web link was sent via e-mail to the landscape managers of the 10 sites. Response rate was $100 \%$. Survey responses were first collected online, followed by a face-toface interview and/or phone interview with the participants to validate that the survey answers were complete and correct.

Plant cover evaluation. On each GR included in the survey, plant cover was evaluated during the growing season, between May and July 2015. Because of the lack of reliable information about species planted at the time the roofs were constructed, only data for species present at the time of study were included. The abundance of individual desirable species (e.g., stonecrop) and undesirable groundcover (weeds or bare ground) were visually estimated in $1-\mathrm{m}^{2}$ frames spaced every $20 \mathrm{ft}$ along a transect through the center of each GR. The number of frame-samples per site varied with the size of the GR with a minimum of 5 and a maximum of 24 . Within each frame, the percent cover of each species was estimated by two observers, and those values were averaged. In addition, cover classes of desirable (planted) species, adventive (weedy) species, and bare ground (including thatch) were recorded. Many of the planted and weedy species had spreading growth habits with overlapping canopies. In such cases, it is common for the sum of the recorded observations for individual species to exceed the overall percent vegetation cover estimate, and may exceed $100 \%$ (Greig-Smith, 1983). Thus, percent 
Table 2. Survey questions distributed to extensive green roof landscape managers to elicit responses about the characterization of the roofs, the substrate and planting descriptions, and the maintenance practices in 2015 for 10 extensive green roof sites in the Research Triangle Area of North Carolina.

\section{Green roof site conditions}

I. Characters of the green roof

1. How old is your green roof? $\left({ }^{*}\right)^{\mathrm{z}}$

2. What is the size, in square feet, of the green roof? $\left.*^{*}\right)$

3 . Is the roof pitched or flat? $\left(^{*}\right)$

4. Indicate specific green roof systems or green roof construction company name.

5. How do you define the sunlight aspect of the roof? (*) (full sun $>6 \mathrm{~h} / \mathrm{d}$, part sun, $<6 \mathrm{~h} / \mathrm{d}$, shade)

6. Can the public see the roof?

7. Can the public walk near the roof plantings?

8. Can people, other than maintenance and facilities staff, gather within the roof plantings?

9. Do you have a maintenance handbook of this roof offered by the construction company manufacturer or maintenance contractor? If yes, do you find it useful?

10. How would you define the performance of the roof? If not successful or a failure, describe why.

II. Planting substrate description

1. What kind of planting substrate is used on the roof? $\left({ }^{*}\right)$

2. How deep is the substrate profile? $\left({ }^{*}\right)$

III. Plant material description

1. Was the roof planted to a single species or multiple species/varieties?

2 . In the areas intended to grow plants, what percentage of the roof is currently growing plants?

IV. Maintenance practices ${ }^{y}$

1. Rate the following maintenance procedure according to how much time is spent. $\left({ }^{*}\right)$

2. What is the average time spent to maintain the green roof? $(*)$

3 . About how much does it cost to maintain this roof per year? $(*)$

1. Irrigation

1. Do you provide supplemental irrigation?

3. How often do you water the plants on an annual average? $\left(^{*}\right)$

4. On average, how long does it take to water the plants each time you water? ${ }^{*}$ )

5 . Is there an automated irrigation system? $\left.{ }^{*}\right)$

2. Weed control

1. How do you manage weeds?

2. How often do you remove weeds? (*)

3. How long does it take to remove the weeds each time? $\left({ }^{*}\right)$

3. Growth control

1. Do you take soil samples for testing?

2. Do you mow or prune the plants?

3 . How often do you prune?

4. How long does it take to prune or mow each time?

4. Fertilizer use

1. Was control-release fertilizer incorporated into the substrate at initial planting time? $(*)$

2. If you use water-soluble fertilizer, how often do you fertilize? (*)

3. How long does it take to fertilize each time? (*)

V. Subjective, open-ended questions

1. What is the biggest challenge in maintaining the roof?

2 . If you could change anything (with no budget constraints) what changes would you make to the roof and why?

3 . Which factor do you think is the most important to the success of your green roof?

${ }^{\mathrm{z}}$ To focus the presentation of results, only the answers of marked questions $\left({ }^{*}\right)$ are reported.

${ }^{\mathrm{y}}$ Based on primary maintenance practices described in the preliminary interview with green roof maintenance professionals, maintenance category was divided into four parts: irrigation, weed control, growth control, and fertilizer. cover of all vegetation was extrapolated as the remainder of $100 \%$ minus the percent bare ground estimates. On some days when sites were visited for observation, it was evident that the site had recently been hand weeded. Consequently, percent weedy plant cover was likely underestimated on those sites. To account for this, a cover-class of weeds plus bare ground was calculated.

Plant cover, site conditions, AND MAINTENANCE COSTS EVALUATION. Statistical software (SAS version 9; SAS Institute, Cary, NC) was used to investigate correlations between the possible site conditions factors and plant cover on the GRs. To conduct correlation analyses the raw survey data were normalized using relative number coding. The proposed favorable conditions for plant growth were coded with higher values and the unfavorable conditions with lower values. Because of sample size differences, Spearman correlation test was used for smaller sample size and Pearson for larger sample sizes.

\section{Results}

Survey. Survey responses for site conditions are presented in Table 3. The 10 study sites varied in size between 1500 and 14,000 $\mathrm{ft}^{2}$, and were 1 to 8 years of age (in 2015). Most sites were in part sun, less than 6 h of direct sun per day, except for site 8 , which had full sun, more than $6 \mathrm{~h}$ of sun per day. There were three common components of the substrates, an expanded slate lightweight aggregate (Permatill; Stalite Environmental, Salisbury, NC), organic matter $(\mathrm{OM})$, and sand. Expanded slate lightweight aggregate was the major component on most roofs. The percentage of weight/total weight of expanded slate lightweight aggregate ranged from $30 \%$ to $100 \%$. OM added to the substrate of $70 \%$ of the sites in amounts ranging from $15 \%$ to $60 \%$ by volume. Site 1 had the highest percentage of $\mathrm{OM}$ at $60 \%$, because of the addition of pine (Pinussp.) bark mulch. Eighty percent of the study GRs had $10 \%$ to $30 \%$ sand as a substrate component, and two sites had no sand. The planting methods of the GRs varied. Five sites used modular preplanted trays in which plant material was established before installation on the rooftop above the drainage layer and a waterproofing membrane. The other roofs 
Table 3. Summary of selected survey responses to questions about site conditions, substrate components, and planting methods for 10 extensive green roofs in the Research Triangle Area of North Carolina.

\begin{tabular}{|c|c|c|c|c|c|c|c|c|c|c|}
\hline \multirow[b]{2}{*}{$\begin{array}{l}\text { Site } \\
\text { no. }^{z}\end{array}$} & \multirow[b]{2}{*}{$\begin{array}{l}\text { Age } \\
(\mathrm{yr})\end{array}$} & \multirow[b]{2}{*}{$\begin{array}{l}\text { Area } \\
\left(\mathrm{ft}^{2}\right)^{\mathrm{y}}\end{array}$} & \multirow[b]{2}{*}{ Sunlight $^{\mathrm{x}}$} & \multicolumn{3}{|c|}{ Substrate components (\%) } & \multirow[b]{2}{*}{$\begin{array}{l}\text { Planting } \\
\text { method }^{v}\end{array}$} & \multirow[b]{2}{*}{ Mulch } & \multirow[b]{2}{*}{$\begin{array}{l}\text { Safety harness } \\
\text { required }\end{array}$} & \multirow[b]{2}{*}{ Irrigation } \\
\hline & & & & Sand & $\begin{array}{l}\text { Organic } \\
\text { matterw }\end{array}$ & $\begin{array}{c}\text { Expanded } \\
\text { slate aggregate }\end{array}$ & & & & \\
\hline 1 & 3 & 6,587 & Part sun & 10 & 60 & 30 & $\begin{array}{l}\text { Preplanted } \\
\text { modular }\end{array}$ & Pine bark & No & $\begin{array}{l}\text { Hand } \\
\text { watered }\end{array}$ \\
\hline 2 & 1 & 3,000 & Part sun & 20 & 20 & 60 & $\begin{array}{r}\text { Preplanted } \\
\text { modular }\end{array}$ & No mulch & Yes & Automated \\
\hline 4 & 8 & 3,991 & Part sun & 30 & 15 & 55 & $\begin{array}{r}\text { Preplanted } \\
\text { modular }\end{array}$ & No mulch & No & None \\
\hline 5 & 7 & 3,685 & Part sun & 10 & 20 & 70 & In situ & No mulch & No & Automated \\
\hline 6 & 8 & 14,100 & Part sun & 30 & 15 & 55 & In situ & No mulch & No & None \\
\hline 7 & 8 & 8,900 & Part sun & 30 & 15 & 55 & $\begin{array}{r}\text { Preplanted } \\
\text { modular }\end{array}$ & No mulch & No & None \\
\hline 9 & 2 & 1,476 & Part sun & 0 & 0 & 100 & In situ & No mulch & No & Automated \\
\hline 10 & 8 & 6,147 & Part sun & 30 & 15 & 55 & $\begin{array}{l}\text { Preplanted } \\
\text { modular }\end{array}$ & No mulch & No & None \\
\hline
\end{tabular}

${ }^{\mathrm{z}}$ The same 10 sites were included in the maintenance survey and vegetation assessments.

$\mathrm{y}_{1} \mathrm{ft}^{2}=0.0929 \mathrm{~m}^{2}$.

${ }^{\mathrm{x}}$ Full sun was defined as $>6 \mathrm{~h} \cdot \mathrm{d}^{-1}$; part sun as $<6 \mathrm{~h} \cdot \mathrm{d}^{-1}$.

whe survey respondents included the pine bark mulch covering the substrate as organic matter.

vPlanting methods: preplanted modules with established plants vs. young plants transplanted in situ into loose substrate on the green roofs.

Table 4. Estimates of cost, time, and frequency of the four primary maintenance practices of weeding, watering, pruning, and fertilizing green roofs. Results are from a survey of site managers for 10 extensive green roofs in the Research Triangle Area of North Carolina.

\begin{tabular}{lcccccccccccc}
\hline & \multicolumn{1}{c}{ Site no. } \\
\cline { 2 - 10 } Maintenance practice & $\mathbf{1}$ & $\mathbf{2}$ & $\mathbf{3}$ & $\mathbf{4}$ & $\mathbf{5}$ & $\mathbf{6}$ & $\mathbf{7}$ & $\mathbf{8}$ & $\mathbf{9}$ & $\mathbf{1 0}$ & Avg \\
\hline Cost $\left(\mathrm{S} / \mathrm{ft}^{2} / \mathrm{yr}\right)^{\mathrm{z}}$ & 2.28 & 0.28 & 0.22 & 0.13 & 0.23 & 0.18 & 0.13 & 3.45 & 1.69 & 0.13 & 0.87 \\
Overall time $\left(\mathrm{h} / \mathrm{ft}^{2} / \mathrm{yr}\right)^{\mathrm{y}}$ & 0.16 & 0.04 & 0.01 & 0.10 & 0.04 & 0.01 & 0.03 & 0.22 & 0.09 & 0.01 & 0.07 \\
Weeding frequency $(\mathrm{no} . / \mathrm{yr})^{\mathrm{x}}$ & 52 & 3 & 30 & 30 & 3 & 30 & 30 & 52 & 30 & 30 & 29 \\
Weeding time $\left(\mathrm{h} / \mathrm{ft}^{2} / \mathrm{yr}\right)$ & 0.04 & $<0.01$ & 0.01 & 0.01 & $<0.01$ & 0.01 & 0.01 & 0.04 & 0.01 & 0.01 & 0.01 \\
Water frequency $(\mathrm{no} / \mathrm{yr})$ & 48 & 90 & 6 & 0 & 12 & 0 & 0 & 96 & 30 & 0 & 28.2 \\
Watering time $\left(\mathrm{h} / \mathrm{ft}^{2} / \mathrm{yr}\right)$ & 0.02 & 0.01 & $<0.01$ & 0.00 & $<0.01$ & 0.00 & 0.00 & 0.05 & 0.01 & 0.00 & 0.01 \\
Fertilizing frequency $(\mathrm{no} . / \mathrm{yr})$ & 1 & 1 & 1 & 0 & 2 & 0 & 0 & 0 & 1 & 0 & 0.6 \\
\hline
\end{tabular}

${ }^{\mathrm{z}}$ Maintenance costs were calculated based on survey estimates of overall annual maintenance costs divided by area of the site; $\$ 1 / \mathrm{ft}^{2}=\$ 10.7639 / \mathrm{m}^{2}$.

${ }^{y}$ Overall time spent on maintenance tasks was calculated based on survey estimates of hours divided by area of the site; $1 \mathrm{~h} / \mathrm{ft}^{2}=10.7639 \mathrm{~h} / \mathrm{m}^{2}$.

${ }^{\mathrm{x}}$ Number of times the activity was performed per year.

used a built-in-place method referred to as planted in situ, in which substrate is placed on the roof surface over a filter fabric, a drainage layer, and a waterproofing membrane, then the chosen species were planted into the substrate (Table 3). Three of the GRs had automated irrigation systems installed at the time of construction; three GRs were hand watered, and four sites provided no supplemental irrigation.

The time spent on maintenance practices ranged from 0.01 to $0.22 \mathrm{~h} /$ $\mathrm{ft}^{2}$ per year (Table 4 ). The yearly cost of maintenance ranged from $\$ 0.13 /$ $\mathrm{ft}^{2}$ to $\$ 3.45 / \mathrm{ft}^{2}$ per year. Although weeding times for the 10 study sites varied from $<0.01$ to $0.04 \mathrm{~h} / \mathrm{ft}^{2}$ per year, among all the maintenance practices, $100 \%$ of the survey respondents ranked weeding as the most timeconsuming task (data not shown). Irrigation and pruning were tied for second most time-consuming tasks, followed by debris removal (data not shown). Due to the different conditions on these roofs, the time spent on irrigation varied from zero to $0.05 \mathrm{~h} /$ $\mathrm{ft}^{2}$ per year (Table 4 ). Although fertilizing did not factor highly in the maintenance costs or time, of the five sites that reported using fertilizer, two kinds were reported: controlledrelease fertilizer (CRF) and watersoluble fertilizer. Site 5 used both CRF and water-soluble fertilizers, whereas the other four sites used only CRF. The labor time on other maintenance practices, such as mowing or pruning, is not reported in this study.

Plant Cover. Differences in the percentage of desirable plant cover were observed among the 10 sites (Table 5). Site 1 had the highest percentage of desirable plant cover $(71.6 \%)$ and site 9 had the lowest percentage of plant cover (26.1\%). The average desirable plant cover 
Table 5. Percent cover estimates on 10 extensive green roofs in the Research Triangle Area of North Carolina. Percent cover for each species was recorded in $1-\mathrm{m}^{2}\left(10.8 \mathrm{ft}^{2}\right)$ quadrats spaced every $20 \mathrm{ft}(6.1 \mathrm{~m})$ on line transects, and then combined into cover classes of desirable vegetation, weedy vegetation, and bare ground.

\begin{tabular}{|c|c|c|c|c|}
\hline \multirow[b]{2}{*}{ Site no. } & Desirable vegetation $^{\mathrm{z}}$ & Weedy vegetation $^{\mathrm{y}}$ & Bare ground & Weedy vegetation + bare ground ${ }^{x}$ \\
\hline & \multicolumn{4}{|c|}{ (Avg \% cover) } \\
\hline 1 & 71.6 & 2.7 & 18.2 & 20.9 \\
\hline 3 & 69.3 & $6.6^{\mathrm{w}}$ & 29.1 & 35.6 \\
\hline 4 & 64.6 & 2.2 & 26.0 & 28.2 \\
\hline 5 & 62.0 & 4.7 & 35.3 & 40.0 \\
\hline 8 & 32.1 & 27.0 & 38.6 & 65.7 \\
\hline 9 & 26.1 & 34.6 & 42.9 & 77.5 \\
\hline 10 & 26.8 & 4.0 & 82.5 & 86.5 \\
\hline Avg & 52.1 & 8.3 & 39.1 & 50.1 \\
\hline
\end{tabular}

${ }^{\mathrm{z}}$ Desirable vegetation refers to species that are commonly recommended for planting on green roofs and are rarely adventive, for example, stonecrop.

${ }^{y}$ Weedy vegetation refers to the adventive species that spontaneously grew on green roofs.

${ }^{\mathrm{x}}$ Combined percent cover of weedy vegetation and bare ground; as the bare ground might ultimately be filled with weedy vegetation, or ground was bare because maintenance staff had removed the weedy species before vegetation assessment.

${ }^{\mathrm{w}}$ Clear evidence was present that these green roofs were weeded just before the cover observations.

Table 6. Percent cover of desirable plant species observed on each of 10 green roofs in the Research Triangle Area of North Carolina. Percent cover for each species was recorded in $1-\mathrm{m}^{2}\left(10.8 \mathrm{ft}^{2}\right)$ quadrats spaced every $20 \mathrm{ft}(6.1 \mathrm{~m})$ on line transects.

\begin{tabular}{|c|c|c|c|c|c|c|c|c|c|c|}
\hline \multirow[b]{2}{*}{ Observed species/varieties } & \multicolumn{10}{|c|}{ Cover of each desirable species by site no. (\%) } \\
\hline & 1 & 2 & 3 & 4 & 5 & 6 & 7 & 8 & 9 & 10 \\
\hline $\begin{array}{l}\text { 'Autumn Joy' stonecrop (Hylotelephium erythrostictum } \\
\text { 'Herbstfreude') }\end{array}$ & 2.3 & - & - & - & - & - & - & 4.6 & - & - \\
\hline Black-eyed susan (Rudbeckia birta) & - & - & - & - & - & - & - & 1.8 & - & - \\
\hline 'Blue Spruce' stonecrop (Sedum rupestre) & - & - & - & - & 2.0 & 6.0 & 0.2 & - & 2.4 & - \\
\hline Blue-green sedge (Carex flacca) & - & - & - & - & - & - & - & 18.3 & - & - \\
\hline 'Coral Carpet' stonecrop (S. album) & 0.2 & - & - & - & - & 5.8 & - & 2.9 & 1.3 & - \\
\hline 'Dragon's Blood' stonecrop (S. spurium) & 5.4 & 8.3 & 2.9 & 0.4 & - & 2.6 & 0.4 & - & - & 2.8 \\
\hline Rose moss (Portulaca grandiflora) & 0.5 & - & - & - & - & - & - & - & - & - \\
\hline Flame flower (Talium calycinum) & - & 2.0 & 2.0 & - & - & 25.4 & - & 17.3 & - & - \\
\hline Ice plant (Delosperma basuticum) & - & - & 25.7 & - & - & - & - & - & - & - \\
\hline Desirable species (no.) & 7 & 5 & 6 & 3 & 3 & 8 & 4 & 6 & 4 & 3 \\
\hline
\end{tabular}

percentage of the 10 sites was $52.1 \%$, suggesting that nearly half of the area of these roofs is either bare ground, thatch, or weedy species.

The number of desirable plant species on the study roofs ranged from three to eight, with stonecrop species/varieties having the highest cover on most GRs (Table 6). However at one site, cover of ice plant (Delosperma basuticum) was nearly that of stonecrop. Although some roofs had as few as three species or varieties, one tended to dominate at $64 \%, 62 \%$, and $23.8 \%$, respectively, as shown in sites 4,5 , and 10 (Table 6).
Although some roofs exhibited a greater variety of plant species and varieties (as many as eight), most of the recorded plant cover was just one or two species. For example, site 6 had seven species of stonecrop, which encompassed $26.8 \%$ of the plant cover and a second genus, flame flower (Talium calycinum) was $25.4 \%$ of the plant cover. On sites 3 and 6 , two species made up $\approx 70 \%$ of the total recorded plant cover. The percent cover of the five recorded species on site 2 were distributed at rates of $31.7 \%$ 'Weihenstephaner Gold' orange stonecrop (Sedum kamtchaticum var. floriferum), 27.3\% tasteless stonecrop (Sedum sexangulare), $8.3 \%$ 'Dragon's Blood' stonecrop (Sedum spurium), 2.0\% flame flower, and $0.2 \%$ 'Chubby Fingers' white stonecrop ( $\mathrm{Se}$ dum album) (Table 6). However, not all of the GRs with diverse plant species had distributions dominated by one or two genera or species. Some plants were generally found in low numbers in the overall sampling, including black-eyed susan (Rudbeckia birta), blue-green sedge (Carex flacca), rose moss (Portulaca grandiflora), and ice plant. Although bluegreen sedge was found on only one 
Table 7. Distribution of desirable plant species cover on 10 green roofs in the Research Triangle Area of North Carolina. Percent cover for each species was recorded in $1-\mathrm{m}^{2}\left(10.8 \mathrm{ft}^{2}\right)$ quadrats spaced every $20 \mathrm{ft}(6.1 \mathrm{~m})$ on line transects. Presented for each species are the number of roofs a species was present, average cover, lowest cover, and highest cover observed (where present).

\begin{tabular}{|c|c|c|c|c|}
\hline \multirow[b]{2}{*}{ Species/variety } & \multirow[b]{2}{*}{ Sites where present (no.) } & \multicolumn{3}{|c|}{ Cover $(\%)$} \\
\hline & & Avg & Low & High \\
\hline $\begin{array}{l}\text { 'Weihenstephaner Gold' orange stonecrop (Sedum } \\
\text { kamtchaticum var. floriferum) }\end{array}$ & 9 & 28.5 & 0.6 & 64 \\
\hline 'Chubby Fingers' stonecrop (Sedum album) & 7 & 2.7 & 0.2 & 7.9 \\
\hline 'Dragon's Blood' stonecrop (Sedum spurium) & 7 & 3.3 & 0.4 & 8.3 \\
\hline Flame flower (Talium calycinum) & 5 & 10.1 & 2 & 25.4 \\
\hline $\begin{array}{l}\text { 'Autumn Joy' stonecrop (Hylotelephium erythrostictum } \\
\text { 'Herbstfreude') }\end{array}$ & 2 & 3.3 & 2.3 & 4.3 \\
\hline 'Blue Spruce' stonecrop (Sedum rupestre) & 2 & 3.1 & 0.2 & 6 \\
\hline Caucasian stonecrop (S. spurium 'Album Superbum') & 2 & 18.6 & 0.4 & 51.5 \\
\hline Three-leaved stonecrop (Sedum ternatum) & 2 & 0.7 & 0.6 & 0.9 \\
\hline
\end{tabular}

${ }^{\mathrm{z}} \mathrm{NA}=$ not applicable. These species were each present on only one roof. Therefore, average cover cannot be calculated.

Table 8. Weed species and estimated cover observed during study of 10 green roofs in the Research Triangle Area of North Carolina. Percent cover of each species was estimated from quadrat sampling on roof transects. Presented for each species are the number of roofs a species was present, average cover, lowest cover, and highest cover observed (where present).

\begin{tabular}{lcccr}
\hline & Sites where & \multicolumn{3}{c}{ Cover (\%) } \\
\cline { 4 - 6 } Wresent (no.) & Avg & Low & High \\
\hline Moss (unidentified) & 8 & 3.9 & 0.5 & 14.9 \\
Crabgrass (Digitaria sp.) & 5 & 0.7 & 0.2 & 1.8 \\
Woodsorrel (Oxalis sp.) & 5 & 1.0 & 0.3 & 1.5 \\
Loblolly pine (Pinus taeda) & 4 & 0.3 & 0.1 & 0.9 \\
Chinese elm (Ulmus parvifolia) & 4 & 0.3 & 0.1 & 0.5 \\
Dandelion (Taraxacum officinale) & 4 & 0.2 & 0.1 & 0.3 \\
Spotted spurge (Euphorbia maculata) & 3 & 2.4 & 0.9 & 4.1 \\
Fleabane (Erigeron strigosa) & 2 & 3.9 & 0.1 & 7.7 \\
White clover (Trifolium repens) & 2 & 9.1 & 7.2 & 11.1 \\
Goldenrod (Solidago sp.) & 1 & NA & NA & 0.3 \\
Common chickweed (Stellaria media) & 1 & NA & NA & 0.1 \\
Dogwood (Cornus florida) & 1 & NA & NA & 0.1 \\
\hline
\end{tabular}

${ }^{\mathrm{z}}$ Not applicable; these species were present on one roof.

roof, it made up an average of $18.3 \%$ of the vegetative cover on that roof (Table 6$)$.

The species encountered with the highest frequency and with the highest average cover was 'Weihenstephaner Gold' orange stonecrop found on $90 \%$ of the studied roofs (Table 7). However, not all prevalent plant species were thriving on the GRs. For example: 'Chubby Fingers' stonecrop and 'Dragon's Blood' stonecrop were found on $70 \%$ of the studied roofs but their overall average percent cover was $2.7 \%$ and $3.3 \%$, respectively, suggesting these two species failed to flourish on our study sites. In contrast, flame flower was found on $50 \%$ of sites, and tasteless stonecrop found on $40 \%$ of sites, had average percent cover of $10.1 \%$ and $16.2 \%$, respectively, and highest percentage cover of $25.4 \%$ and $27.5 \%$, respectively, indicating that when present, these species established and persisted (Table 7). The species with the highest average percent cover on any specific GR were "Weihenstephaner Gold' orange stonecrop at 28.5\%; tasteless stonecrop at $16.2 \%$; caucasian stonecrop (S. spurium 'Album Superbum') at 18.6\%; and flame flower at $10.1 \%$ (Table 7).
Weed populations on GRs. Weedy vegetation covered between $2.2 \%$ and $34 \%$ of the GRs (Table 5 ). Most roofs in this study received regular maintenance, including weed removal, the schedules for which were beyond the researcher's control. Thus, a combined vegetation class of bare ground plus weedy vegetation was calculated and accounted for $20.9 \%$ to $86.5 \%$ cover (Table 5 ). The most frequently observed adventive plant species (weedy vegetation) were unidentified mosses, which were present on $80 \%$ of roofs (Table 8 ). Average percent cover of mosses was $3.9 \%$, although cover was as high as $14.9 \%$ on one roof and as low as 0.05\%. Crabgrass (Digitaria sp.) and woodsorrel (Oxalis sp.) were found on $50 \%$ of roofs; loblolly pine (Pinus taeda) and chinese elm (Ulmus parvifolia) tree seedlings, and dandelion (Taraxacum officinale) were found on $40 \%$ of roofs. Although present on only $20 \%$ of roofs, the average cover of white clover (Trifolium repens) was $9.1 \%$ (Table 8 ).

COMPARISON OF PLANT COVER, SITE CONDITIONS, AND MAINTENANCE COSTS/ TIME. A summary of correlations between site conditions and plant cover is found in Table 9. Roof age, roof size, $\mathrm{OM}$, and planting methods were not correlated with desirable plant cover (Table 9).

Comparisons among maintenance practices and vegetative cover are shown 
Table 9. Summary of correlation coefficients $(r)$ and associated probability values $(P)$ for comparisons between site conditions and plant cover on 10 green roofs in the Research Triangle Area of North Carolina.

\begin{tabular}{lrcc}
\hline Correlation $^{\mathrm{z}}$ & $\boldsymbol{r}$ & $\boldsymbol{P}$ & Correlation method $^{\mathrm{y}}$ \\
\hline Roof age vs. plant cover (\%) & -0.21 & 0.55 & Spearman \\
Roof area vs. plant cover & -0.05 & 0.88 & Spearman \\
Organic matter vs. desirable plant cover & 0.36 & 0.30 & Pearson \\
Organic matter vs. undesired cover & -0.53 & 0.12 & Pearson \\
Planting method vs. plant cover & 0.02 & 0.96 & Pearson \\
\hline
\end{tabular}

${ }^{\mathrm{z}}$ Comparisons from site conditions reported by survey respondents with measured cover. Plant cover was calculated as $100 \%$ minus the percent bare ground. Undesirable plant cover is defined as the sum of percent cover of weeds plus percent bare ground. Organic matter is the binomial presence or absence of added organic matter, regardless of the proportion.

${ }^{\mathrm{y}}$ Spearman correlation test was used for smaller sample size and Pearson for larger sample sizes.

Table 10. Summary of correlation coefficients $(r)$ and associated probability values $(P)$ for comparisons between maintenance practices, vegetation cover and maintenance costs for 10 green roofs in the Research Triangle Area of North Carolina.

\begin{tabular}{lrrc}
\hline Correlation $^{\mathrm{z}}$ & $\boldsymbol{r}$ & $\boldsymbol{P}$ & Correlation method $^{\mathbf{y}}$ \\
\hline Watering time vs. desirable plant cover & 0.24 & 0.47 & Spearman \\
Watering time vs. weed cover & 0.27 & 0.43 & Spearman \\
Watering time vs. bare ground & -0.56 & 0.07 & Spearman \\
Cost vs. watering time & 0.89 & 0.02 & Spearman \\
Cost vs. desirable plant cover & -0.32 & 0.34 & Pearson \\
Cost vs. weed cover & 0.58 & 0.06 & Pearson \\
Cost vs. weeding time & 0.89 & $<0.01$ & Pearson \\
Cost vs. safety harness requirement & 0.62 & 0.05 & Pearson \\
\hline
\end{tabular}

${ }^{\mathrm{z}}$ Watering times, cost estimates, and safety harness requirements were derived from a survey of 10 green roof site managers. Plant and weed cover were measured on the same roofs.

${ }^{y}$ Spearman correlation test was used for smaller sample size and Pearson for larger sample sizes. Supplemental irrigation was not used on all green roofs in the study resulting in a smaller sample size for these comparisons.

in Table 10. Irrigation time was negatively correlated with percent bare ground, which indicates that greater irrigation use may increase overall plant cover, for both desirable and weedy plants (Table 10). The cost of maintenance is positively correlated with weedy plant cover as well as time spent weeding or watering. This suggests overall maintenance costs were more correlated with labor-intensive tasks like weed removal and hand watering than with other maintenance practices (Table 10). In addition, sites requiring the use of safety harnesses had greater maintenance costs.

Although most of the relationships among the proposed factors potentially influencing the desirable and weedy plant cover are not significant on some sites, sites $2,3,4$, and 5 ( $40 \%$ of GRs) did have a high desirable plant cover with relatively low maintenance time and cost ( $\mathrm{Ta}$ bles 4 and 5 ). These four GRs with high desirable plant cover had maintenance costs per year within $\$ 0.13$ to $\$ 0.28$ in common
$50 \%$ OM allowed for lush plant growth in wet regimes. In addition, they found that high $\mathrm{OM}$ in dry substrates does not increase plant growth. According to Whittinghill and Rowe (2012), pine bark in the substrate typically resulted in higher productivity. In contrast, our findings did not show a positive correlation between OM and number or percent cover of observed species, either desirable or weedy plants (Table 9).

IRRIGATION. Irrigation on extensive GRs is controversial. In this study, irrigation time was negatively correlated with percent bare ground, indicating irrigation increased percent plant cover. Yet, in this study, one site with high vegetative cover received no supplemental irrigation. Price et al. (2011) support the need for irrigation use, asserting that irrigation influenced survival during the summer period by lowering substrate temperature, and only succulent plants like stonecrops survived without irrigation. According to Van Woert et al. (2005), although irrigation is not critical once vegetation is established, the primary goal during establishment is to achieve $100 \%$ plant cover as soon as possible to inhibit weeds, reduce wind and water erosion, and achieve desired esthetics qualities. Thus, watering during plant establishment period and then watering only when necessary could result in higher vegetative cover and lower maintenance expenses.

Weeds. Survey respondents ranked weeding as the most timeconsuming practice and thus an expensive maintenance practice. Costs increased with increased frequency of weeding and time spent on this task. A study of weeds on GRs suggested that weeding six times per year was sufficient to keep low numbers of weed colonization during the establishment for semiextensive GRs in northern England (Getter and Rowe, 2006). Our survey results suggest that manual weed control will be an on-going expense. Strategically managing the weeds is therefore very important to the success of a GR and to reducing maintenance costs. At present, no herbicides are specifically registered for use on GRs by the U.S. Environmental Protection Agency; therefore, current landscape weed management recommendations for GRs exclude this strategy. 
Mulches applied at a depth of $>7 \mathrm{~cm}$ can reduce weed incidence and retain moisture in landscape plantings (Greenly and Rakow, 1995; Marble, 2015). Similarly Nagase et al. (2013) reported the use of inorganic (gravel) mulch and increasing the planting density on GRs can reduce the number of weeds significantly. However, time spent weeding the two sites in this study with mulch (site 1 with pine bark mulch and site 8 with expanded slate lightweight aggregate) was equal to or greater than time spent hand weeding the other eight sites (Table $4)$. It is unclear from these data whether the higher weeding times at these sites were related to the mulch itself or a component of overall higher maintenance intensity compared with other sites. To exclude weed growth, nearly $100 \%$ cover of desirable vegetation would be necessary. Research in turfgrass has demonstrated that crabgrass can emerge and mature in a vegetation "gap" only $2.5 \mathrm{~cm}$ in diameter (Kim et al., 1997). Similarly, to prevent emergence of seed-propagated weeds in perennial groundcover plantings, the canopy must be dense enough to reduce light transmission to the soil by at least $80 \%$ (Eom et al., 2005). However, the maximum desirable vegetation cover recorded for the study GRs was $71.6 \%$, leaving large amounts of bare ground for weed emergence. Optimizing desirable plant density warrants further study, as does more characterization and study of how adventive plant communities may contribute to the functional performance of GRs. Presence of certain low-growing weedy forbs, such as moss and white clover, may be acceptable or even desirable, whereas tree seedlings could damage roof structures and aggressive weedy species may displace planted desirable species. Plant species previously viewed as weedy may provide an opportunity for functional vegetative cover where GR aesthetics are not of paramount concern.

SElection of adaptive Plants. Plant selection is important for the long-term success of extensive GRs. Currently, with no GR design standards in North Carolina, designers do not know what vegetation to select for successful GR construction (Moran, 2004). When looking for suitable GR plant species, one way to improve GR plant performance is to target natural ecosystems with similar characteristics as found on GR (Van Mechelen, 2015). Although stonecrop are broadly adapted to GRs, other species may also be well adapted. Previous research conducted by Moran (2004) recommended the use of tasteless stonecrop in extensive GR construction in eastern and central North Carolina. Our data support this recommendation; tasteless stonecrop was persisting on three roofs but at a maximum of $27.3 \%$ cover. Similarly, Rowe et al. (2012) reported that caucasian stonecrop covered most of the roof area at $2.5 \mathrm{~cm}$ substrate depth. In this study, caucasian stonecrop was only found on two study roofs, accounting for more than $50 \%$ cover on one but less than $1 \%$ cover on the other. As seen in this study, although stonecrop species have received the most attention in research and are the most commonly planted species on European and North American GRs (Oberndorfer et al., 2007), some stonecrop may not be adaptable to the stressful high summer night temperatures (Getter and Rowe, 2006) as found in the North Carolina RTA. For use on GRs in the RTA, sedum species should be evaluated for their ability to adapt to high summer temperatures and humidity. This study's results suggest nonstonecrop species such as flame flower and blue-green sedge established well on the study roofs and warrant further evaluation.

Maintenance costs. Previous research regarding GR maintenance indicates that proper maintenance protects GR investment and ensures the GR system achieves its original intent, whether for thermal performance, stormwater management, or aesthetic value (Curtland, 2013). Early research suggesting GRs need no maintenance at all (Williams, 2005) have since been proven incorrect. In the study, hand weeding and irrigation were the most costly maintenance practices. Yet, in this study, higher maintenance costs did not uniformly result in greater desirable plant cover. The two roofs with highest maintenance costs, sites 1 and 8 , were weeded weekly and hand watered but desirable plant cover was $71.6 \%$ and $32.1 \%$, respectively. The roof with the third highest maintenance cost was site 9 that had automated irrigation and low weeding frequency, but only $26 \%$ cover of desirable species. In addition, maintenance costs were greater where weed cover was greater. Detailed guidelines to optimize irrigation regimens that would improve plant performance, and improved weed management options for GRs in the southeastern United States are needed. There is a need to evaluate factors correlated with success in controlled experimentation that is more comprehensive. These evaluations are needed to develop management strategies that reduce maintenance costs and test management and design options promoting long-term success for plant cover on extensive GRs in the RTA. Trends identified in this study suggest that designing GRs for long-term success should include the following: choosing effective watering/ irrigation methods, implementing efficient weed management strategies, and making informed plant selections tailored to the region and GR environmental conditions.

\section{Literature cited}

Acks, K. 2006. A framework for cost-benefit analysis of green roofs: Initial estimates, green roofs in the metropolitan region: Research report. 4 Nov. 2014. <https:// pdfs.semanticscholar.org/4ece/8da2e ae9be12b6141780887be3ae21732c86. pdf $>$.

Beck, H.E., N.E. Zimmermann, T.R. McVicar, N. Vergopolan, A. Berg, and E.F. Wood. 2018. Present and future Köppen-Geiger climate classification maps at $1-\mathrm{km}$ resolution. Sci. Data 5: 180214.

Carter, T. and A. Keeler. 2008. Life-cycle cost-benefit analysis of extensive vegetated roof systems. J. Environ. Manage. 87:350-363.

Clark, C., P. Adriaens, and F. Talbot. 2008. Green roof valuation: A probabilistic economic analysis of environmental benefits. Environ. Sci. Technol. 42:21552161.

Curtland, C. 2013. 4 Strategies for green roof maintenance. Cedar Rapids, IA. 4 Nov. 2012. <https://www.buildings.com/ article-details/articleid/15082/title/4strategies-for-green-roof-maintenance $>$.

Dunnett, N., A. Nagase, R. Booth, and P. Grime. 2008. Influence of vegetation composition on runoff in two simulated green roof experiments. Urban Ecosyst. 11:385-398.

Eom, S.H., A.F. Senesac, I. TsontakisBradley, and L.A. Weston. 2005. Evaluation of herbaceous perennials as weed suppressive groundcovers for use along 
roadsides or in landscapes. J. Environ. Hort. 23:198-203.

Farrell, C., C. Szota, N.S.G. Williams, and S.K. Arndt. 2013. High water users can be drought-tolerant: Using physiological traits for green roof plant selection. Plant Soil 372:177-193.

Fioretti, R., A. Palla, L.G. Lanza, and P. Principi. 2010. Green roof energy and water related performance in the Mediterranean climate. Build. Environ. 45:18901904.

Getter, K.L. and D.B. Rowe. 2006. The role of extensive green roofs in sustainable development. HortScience 41:12761285 .

Getter, K.L., D.B. Rowe, G.P. Robertson, B.M. Cregg, and J.A. Andresen. 2009. Carbon sequestration potential of extensive green roofs. Environ. Sci. Technol. 43:7564-7570.

Greenly, K. and D.A. Rakow. 1995. The effect of wood mulch type and depth on weed and tree growth and certain soil parameters. J. Arboric. 21:225-232.

Greig-Smith, P. 1983. Quantitative plant ecology. 3rd ed. Univ. California Press, Berkeley, CA.

Kim, T.J., J.C. Neal, and F.S. Rossi. 1997. Ecological aspects of crabgrass infestation in cool-season turf. Proc. Northeastern Weed Sci. Soc. 51:40.

Li, Y., J. Babcock, and W. Roger. 2014. Green roof hydrologic performance and modeling: A review, water science and technology. J. Intl. Assn. Water Pollut. Res. 69:727-738.

Lundholm, J., A. Heim, S. Tran, and T. Smith. 2014. Leaf and life history traits predict plant growth in a green roof ecosystem. PLoS One 9:e101395. <https:// journals.plos.org/plosone/article? $\mathrm{id}=10.1371 /$ journal.pone. $0101395>$.

Marble, S.C. 2015. Herbicide and mulch interactions: A review of the literature and implications for the landscape maintenance industry. Weed Technol. 29:341349 .

Moran, A.C. 2004. A North Carolina field study to evaluate green roof runoff quantity, runoff quality, and plant growth. PhD Diss., North Carolina State Univ., Raleigh.
Mullen, J., M. Lamsal, and G. Colson. 2013. Green roof adoption in Atlanta, Georgia: The effects of building characteristics and subsidies on net private, public, and social benefits. Environ. Sci. Technol. 47:10824-10831.

Nagase, A., N. Dunnett, and M. Choi. 2013. Investigation of weed phenology in an establishing semi-extensive green roof. Ecol. Eng. 58:156-164.

Nagase, A. and N. Dunnett. 2012. Amount of water runoff from different vegetation types on extensive green roofs: Effects of plant species, diversity and plant structure. Landsc. Urban Plan. 104:356363.

Nagase, A. and N. Dunnett. 2011. The relationship between percentage of organic matter in substrate and plant growth in extensive green roofs. Landsc. Urban Plan. 103:230-236.

Niu, H., C. Clark, J. Zhou, and P. Adriaens. 2010. Scaling of economic benefits from green roof implementation in Washington, DC. Environ. Sci. Technol. 44:4302-4308.

North Carolina State University. 2020. NC climate synopsis. 6 June 2020. <https://climate.ncsu.edu/climate/ synopsis $>$.

Oberndorfer, E., J. Lundholm, B. Bass, R.R. Coffman, H. Doshi, N. Dunnett, S. Gaffin, M. Köhler, K.K. Liu, and B. Rowe. 2007. Green roofs as urban ecosystems: Ecological structures, functions, and services. Bioscience 57:823-833.

Price, J.G., S.A. Watts, A.N. Wright, R.W Peters, and J.T. Kirby. 2011. Irrigation lowers substrate temperature and enhances survival of plants on green roofs in the southeastern United States. HortTechnology 21:586-592.

Prince George's County Department of the Environment. 2016. Guidelines for green roofs. 12 Oct. 2016. <https:// www.princegeorgescountymd.gov/ DocumentCenter/View/24827/ Guidelines_Green-Roofs_02_19_2019? bidId $=>$.

Rowe, D.B. 2011. Green roofs as a means of pollution abatement. Environ. Pollut. 159:2100-2110.
Rowe, D., K.L. Getter, and A.K. Durhman. 2012. Effect of green roof media depth on crassulacean plant succession over seven years. Landsc. Urban Plan. 104:310-319.

Santamouris, M. 2014. Cooling the cities A review of reflective and green roof mitigation technologies to fight heat island and improve comfort in urban environments. Sol. Energy 103:682-703.

Shao, T. 2012. Economic value of urban roof greening comprehensive benefits - A case study of Futian district, Shenzhen, China. 4 Nov. 2014. <https://www. semanticscholar.org/paper/Resourcepotential-assessment-of-urban-roof-andin-Tianran-Chaosu/c9344de8ed3dleb 6f4ba882cl 0 fd 8 bccc 7 a 2 dfdf $>$.

Van Mechelen, C. 2015. Nature as a template for a new concept of extensive green roofs. PhD Diss., Univ. Avignon, Avignon, France. Diss. Abstr. 015AVIG0334.

VanWoert, N.D., D.B. Rowe, J.A. Andersen, C.L. Rugh, T. Fernandez, and L. Xiao. 2005. Green roof stormwater retention: Effects of roof surface, slope, and media depth. J. Environ. Qual. 34:1036-1044.

Veisten, K., Y. Smyrnova, R. Klæboe, M. Hornikx, M. Mosslemi, and J. Kang. 2012. Valuation of green walls and green roofs as soundscape measures: Including monetised amenity values together with noise-attenuation values in a cost-benefit analysis of a green wall affecting courtyards. Intl. J. Environ. Res. Public Health 9:3770-3788.

Whittinghill, L.J. and D.B. Rowe. 2012. The role of green roof technology in urban agriculture. Renew. Agr. Food Syst. 27:1-9.

Williams, A. 2005. Hines suggests that green roofs need no maintenance at all including watering. Architects' J. 221:38.

Yang, J., Q. Yu, and P. Gong. 2008. Quantifying air pollution removal by green roofs in Chicago. Atmos. Environ. 42:7266-7273.

Yao, L., A. Chini, and R. Zeng. 2020. Integrating cost-benefits analysis and life cycle assessment of green roofs: A case study in Florida. Hum. Ecol. Risk Assess. 26:443-458. 